\title{
ANALYSIS OF THE AVAILABILITY OF SPATIAL DATASETS DEFINED BY THE 3rd ANNEX OF THE INSPIRE DIRECTIVE IN POLAND
}

\author{
${ }^{1}$ AGH University of Science and Technology, \\ artkraw@agh.edu.pl
}

Keywords: INSPIRE, SDI services, environmental data, open data

\begin{abstract}
The article describes changes in the usage of spatial information taking place in the field of environmental engineering and protection over the last 20 years when the analogue maps have been phased out in favour of digital maps. The importance of EU INSPIRE Directive for the popularization of the services for sharing spatial data in order to adopt an environmental policy implemented under the "environmental" EU Directive is discussed.

The article describes the main ways of using spatial information in environmental engineering and protection. Then it discusses the problem of the openness of public administration data in the context of the "Open Data" EU Directive. Based on the four criteria defined by the author, the accessibility of data sets for all 21 subjects of $3^{\text {rd }}$ Annex to the INSPIRE Directive in Poland has been analyzed. The key evaluation parameter has been the accessibility of data downloadable without the requirement to log in to the system of the service provider. The summary presents the research results, and the conclusions contain the proposed methods of solving them.
\end{abstract}

\section{ANALIZA DOSTĘPNOŚCI ZBIORÓW DANYCH PRZESTRZENNYCH OKREŚLONYCH W 3. ANEKSIE DYREKTYWY INSPIRE W POLSCE}

Slowa kluczowe: INSPIRE, usługi SDI, dane o środowisku, otwarte dane

\section{Abstrakt}

W artykule scharakteryzowano zmiany wykorzystania informacji przestrzennej, które w przeciągu ostatnich 20 lat dokonały się w dziedzinie inżynierii i ochrony środowiska i spowodowały odejście od map analogowych na rzecz map cyfrowych. Omówiono znaczenie Dyrektywy INSPIRE UE dla upowszechnienia usług udostępnienia danych przestrzennych w celu prowadzenia polityki środowiskowej realizowanej w ramach Dyrektywy „,́rodowiskowej” UE. Scharakteryzowano główne kierunki wykorzystania informacji przestrzennej w inżynierii i ochronie środowiska. Następnie omówiono problem otwartości danych administracji publicznej w kontekście Dyrektywy „otwartych danych” UE. Na podstawie zdefiniowanych przez autora 4 kryteriów przeanalizowano dostępność zbiorów danych wszystkich 21 tematów 3. Aneksu Dyrektywy INSPIRE w Polsce. Kluczowym parametrem oceny była dostępność danych do pobrania bez konieczności logowania się do systemu dostawcy usługi. W podsumowaniu zaprezentowano wyniki badań, a we wnioskach wskazano na proponowane metody ich rozwiązania.

\section{INTRODUCTION}

For the implementation of many actions taken in the field of environmental engineering and protection, cartographic maps of the Earth surface are required, e.g., in order to analyse the spatial distribution of selected characteristics of the environment. In the past, the background data were usually in the form of paper sections of topographic maps used in different scales, and the master maps. The usage of those cartographic resources 
was restricted by law and charged with relatively high acquisition costs. In that period, the environmental content was drawn by hand on paper copies of topographic maps. The product contained information on the state of the environment and the research results relating to it. Such type of cartographic data was called thematic maps. The government administration also provided guidelines on the creation of thematic maps such as ecological, environmental, soil-agricultural, geomorphological, hydrological, and many more. The main content of those maps was the drawn ranges of various spatial distribution types of environmental features and the state of the environmental changes caused by human activities.

In the last 20 years, both the form of data and legal conditions have changed profoundly. The technology of computerization and processing of data has undergone significant changes in the processing of spatial data. First, the CAD (Computer Aided Design) systems were applied to map production, then GIS (Geographic Information System) systems were applied to perform spatial analyses. However, the use of these possibilities was limited for two reasons: (1) the use of different data formats in GIS systems hindered their exchange and sharing, and (2) the data held by public institutions were difficult to access and initially very expensive to acquire. In that period, users of administrative data often had the choice between the purchase of a cheaper paper map, and a many times more expensive digital map. In the following years, there was a breakthrough owing to the INSPIRE Directive that established the national infrastructure for spatial data in Europe (Parliament and Council, 2007). The primary purpose of the INSPIRE Directive is the implementation of regulations "for the purposes of Community environmental policies and policies or activities which may have an impact on the environment". The implementation of this directive was supposed to directly influence the increase of the level of environmental protection on a European scale, through eliminating the technical problems related to sharing and exchanging the data between the offices and the data users by correlating the knowledge and information from different sectors. The accessibility and openness of that data affects carrying out tasks in the field of environmental protection in a significant way. Those principles were to be achieved through the use of advanced SDI (Spatial Data Infrastructure) technology and because of legislative and organisational changes related to the sharing of data. As part of the Directive,
34 subjects were formulated in 3 annexes - the subjects are domains of data sets that in the framework of this directive all member states are obliged to share.

In Poland, the legal and organisational changes were implemented in the Act of Infrastructure for Spatial Information (Sejm, 2010) in 2010. In order to spread the work over time, an implementation schedule for subsequent annexes, taking into account the launching of consecutive network services and metadata sets, was developed in the framework of the Directive. By 2010 in Poland, both in local governments and in governmental administration, a series of study and implemented works related to the implementation of the Directive was conducted. These actions were conducted both in the field of the construction of infrastructure nodes, and in matters of the standardisation of data and the collecting of that data. Despite the task schedule set by the directive, the results of those tasks are not always fully achievable. The lack of coordination in regard to the implementation of the directive is pointed out to be one of the main problems (Gaździcki, 2017). It results in the situation where work on sharing the data is spread unevenly. In the meantime, as part of the directive, a schedule for the data set of $3^{\text {rd }}$ Annex defining attaining on 21/10/2020 the state in which all data sets of the Annex are in accordance with the implemented regulations and will be available through the network services, was prepared. In June 2020 only 4 months left to this deadline and thus it is important to inspect the data resources shared in the framework of the implementation of the INSPIRE Directive.

\section{THE PRIMARY DIRECTIONS OF APPLICATION OF THE SPATIAL INFORMATION IN THE ENVIRONMENTAL ENGINEERING AND PROTECTION}

The main part of the forming of the environmental policy is the legislative acts regulating the rules of shaping and transforming the environment by humans. The key factors are the assessments of the environmental impact of proposed and existing infrastructure and industrial investments. The impact evaluations are performed based on the EU Directive (Parliament and Council, 2014). The regulations for this directive are implemented under the Polish law in the framework of Act of $3^{\text {rd }}$ October 2008 on sharing information about the environment and its protection, public participation 
in environmental protection and environmental impact assessment (Sejm, 2008). Both legal acts have undergone changes several times, but the public participation in the protection of the environment and the requirements to be followed during the environmental impact assessment of investments are constantly maintained. Poland has already started study the relationship between the requirements of the environmental impact assessment and the demand on spatial data defined as part of all 3 Annexes of the INSPIRE Directive (Kozakiewicz, 2015). This study was performed in theoretical aspect by means of comparing the definitions of datasets contained in the Directive with the requirements referring to the range of the research during the evaluation of the impact on the environment. However, a few months before the end of the following phase of the implementation of the INSPIRE Directive, there ought to be a verification of the current state of these resources - which ones are open and freely available to the society, and which ones are still not accessible.

Because of the high demand on data for analyses of human mining activity, the INSPIRE data have also become a subject of research on the possibility of applying them to opencast mining (Bac-Bronowicz et al., 2016). In the research there is a definition which types of INSPIRE spatial data can be used for the preparation of various types of geological-mining documentation. The application of the spatial data defined in the INSPIRE Directive is also possible for the underground mining (Krawczyk, 2019).

The third branch of environmental engineering and protection, that awaits the access to the data, is spatial planning. This type of data can noticeably help in changing, and in a way standardizing, the basics for the analysis procedures during the creation and coordination of the land use plans (Kaczmarek et al., 2014). The other side of the problem is, the preparation of the missing, and the publication of the existing land use plans in accordance with the INSPIRE Directive requirements (Pluta, 2016).

\section{ANALYSIS OF DATASETS OF 3RD ANNEX OF THE INSPIRE DIRECTIVE}

All 21 subjects of the 3rd annex of INSPIRE Directive have been analysed. Table 1 lists their names and numbers (in accordance with the Directive's annex), and names of agencies the subjects were assigned to.
Four criteria of assessing the matching datasets were adopted for the study: sharing for viewing purposes, openness of data (downloading of data), use of network services for data, sharing of data files and the standard of coding text attributes.

The criterion of sharing data for viewing purposes allows the evaluation of the amount of data that has already been prepared to meet the requirements of the INSPIRE Directive. Whether the data are available for download in the future usually depends on organisational and legal factors. This criterion will allow for the identification of subjects that have no datasets available.

The key analysis criterion, however, is the openness of data: are the data from respective INSPIRE subjects available for easy downloading, is the access to them in some way restricted? The open data are defined as shared data that can be downloaded in public interest with no restrictions on usage or distribution (Geiger and von Lucke, 2012). Other researchers likewise assume that in terms of their own studies on data availability, open data means data available without a requirement of creating an account and logging into the service (Quarati and Martino, 2019). The act of logging in limits the openness of data and severely hinders the use of data by the people from other EU countries. Openness of data has also become a substantial factor in European politics. On $20^{\text {th }}$ June 2019, a Directive on open data and the re-use of public sector information (Parliament and Council, 2019) was passed. Member states have to transpose the directive into their domestic legal systems by $16^{\text {th }}$ July 2021 . This directive formalises and legalises the sharing of public data as open data for re-use not only by government institutions, but also by the EU societies.

The identified datasets that were made available for downloading, were analysed with a view to the data being consistent with the standards such as data format and the application of correct code pages for diacritics. In some cases, the number of descriptive attributes associated with a geometric object was assessed.

The last criterion is the verification of the code page used for the writing of descriptive attributes in a given dataset. As the analyses performed by J. Michalak (Michalak, 2004) show that the INSPIRE datasets for Poland should be created with the use of UTF- 8 code page. Because of this, as part of the performed analyses, the code page for text descriptions in a given dataset was also analysed in the available datasets. 
Tab. 1. Subjects of datasets of the 3rd Annex of the INSPIRE Directive, and the leading agencies

Tab. 1. Tematy zbiorów danych 3. Aneksu Dyrektywy INSPIRE wraz z organami wiodącymi

\begin{tabular}{|c|c|}
\hline Subject of the 3rd Annex of the directive & Agency responsible for the data \\
\hline 1. Statistical units & President of the Statistics Poland (GUS) \\
\hline 2. Buildings & Surveyor General of Poland \\
\hline 3. Soil & Surveyor General of Poland \\
\hline 4. Land use & Surveyor General of Poland \\
\hline 5. Human health and safety & Ministry of Health \\
\hline 6. Utility and governmental services & Surveyor General of Poland \\
\hline 7. Environmental monitoring facilities & Chief Inspector of Environmental Protection \\
\hline 8. Production and industrial facilities & Surveyor General of Poland \\
\hline 9. Agricultural and aquaculture facilities & Director of the Institute of Technology and Life Sciences \\
\hline 10. Population distribution - demography & President of the Statistics Poland (GUS) \\
\hline $\begin{array}{l}\text { 11. Area management/restriction/regulation zones } \\
\text { and reporting units }\end{array}$ & Surveyor General of Poland \\
\hline 12. Natural risk zones & Chief Inspector of Environmental Protection \\
\hline 13. Atmospheric conditions & $\begin{array}{l}\text { Principal CEO of Institute of Meteorology and Water } \\
\text { Management - National Research Institute }\end{array}$ \\
\hline 14. Meteorological geographical features & $\begin{array}{l}\text { Principal CEO of Institute of Meteorology and Water } \\
\text { Management - National Research Institute }\end{array}$ \\
\hline 15. Oceanographic geographical features & Ministry of Marine Economy and Inland Navigation \\
\hline 16. Sea regions & Chief National Geologist \\
\hline 17. Bio-geographical regions & General Director for Environmental Protection \\
\hline 18. Habitats and biotopes & General Director for Environmental Protection \\
\hline 19. Species distribution & General Director for Environmental Protection \\
\hline 20. Energy resources & Chief National Geologist \\
\hline 21. Mineral resources & Chief National Geologist \\
\hline
\end{tabular}

A negative result of the lack of spatial data available for download is the delay of works related to the harmonisation of national spatial data, as well as the harmonisation with the international standards. The research (Garguła and Krawczyk, 2018) conducted as a part of the harmonisation of one of the datasets already published in Poland has shown that to some extent it is incompatible with the INSPIRE profile and requires further complementation.

\subsection{Review of subjects for which there are no datasets available to download}

In Poland, the implementation of the subject number 9 "Agricultural and aquaculture facilities" falls under the responsibilities of the Ministry of Agriculture and
Rural Development (Polish: Ministerstwo Rolnictwa i Rozwoju Wsi; MRiRW). The Ministry commissioned the integration and harmonisation of spatial datasets in the framework of the subject from the Institute of Technology and Life Sciences (Polish: Instytut Technologiczno-Przyrodniczy; ITP) in Falenty. Unfortunately, the Geoportal and MRiRW websites lack any links and information for the search, browsing and download services for the datasets related to this subject. In the publication (Dąbkowski et al., 2014) there is a description of problems with the creation of such type of resource in accordance with the requirements of the INSPIRE specification D2.8.III.9 Data Specification on Agricultural and Aquaculture Facilities - Technical Guidelines. The problems are related mostly to the lack of a national registration system of privately-owned agricultural crops 
irrigation devices. The creation of datasets for this subject is nonetheless needed not only for formal reasons, but as the survey research for data from this subject has shown (Pluto-Kossakowska et al., 2016), the demand for them is high.

The GUGIK-run website for registering spatial datasets and data services lacks a direct connection between the available links and the content of the subject. As an example, for unknown reasons, the links to BOT10k sharing services were attached to this subject.

Subject number 15 applies to "Oceanographic geographical features" and is assigned to the Ministry of Marine Economy and Inland Navigation (Polish: Ministerstwo Gospodarki Morskiej i Żeglugi Śródlądowej; MGMiŻŚ). In the framework of the INSPIRE Directive, the overseeing of this subject has been assigned to IMGW-PIB. The websites of IMGW-PIB, the national Geoportal, and the MGMiŻŚS contain no links to data search, browsing or download services.

The leading agency for the subject number 19 "Species distribution" is the Ministry of Environment (Polish: Ministerstwo Środowiska), which commissioned the implementation of this subject to the General Directorate for Environmental Protection (Polish: Generalna Dyrekcja Ochrony Środowiska; GDOŚ). On the websites of GDOŚ and the national Geoportal there is no information regarding the links to dataset search, browsing and download services for this subject. The GUGIK website for Registering spatial datasets and data services, this subject is linked to the "Invasive Alien Species" (Polish: Inwazyjne Gatunki Obce) dataset from the GDOŚ website, but it is not a significant element of this subject. This dataset can be used as a supplementation to this subject, but cannot be its content.

\subsection{Subjects with limited availability to the downloading of datasets}

Many subjects of the 3rd Annex shared through the national Geoportal are available for the download of spatial datasets via the download service after being granted the permission from the Surveyour General of Poland (Polish: Główny Geodeta Kraju). To acquire this data, firstly, one has to inquire about it via email to this address: geoportal@geoportal.gov.pl. This method of data sharing is in accordance with the INSPIRE Directive, but is incompatible with the idea of open data. The subjects that require gaining an authorisation are: a) no. 2 - "Buildings",

b) no. 3-,Soil",

c) no. 5 - „Human health and safety”,

d) no. 6 - „Utility and governmental services”,

e) no. 8 - „Production and industrial facilities”,

f) no. $11-$,Area management/restriction/regulation zones and reporting units",

g) no. $16-$, ,Sea regions”.

\subsubsection{Comments on the dataset for the 7th subject 'Environmental monitoring facilities'}

Data from the dataset number 7, "Environmental monitoring facilities", are managed by the Chief Inspectorate of Environmental Protection (Polish: Główny Inspektorat Ochrony Środowiska) and concern the localisation and the functioning of these facilities. The Inspectorate has created a specialized "GIOŚInspire" website which has the CSW (Catalogue Service for the Web) search standard that complies with the INSPIRE standards. The data can be browsed with the WMS service, whereas the data download is done using *.GML files. To download the data one has to log into the server, as the data cannot be downloaded without first being granted the registration and getting the permission from the agency managing the data.

\subsubsection{Comments on the dataset for the 8th subject 'Production and industrial facilities'}

In Poland, subject "Production and industrial facilities" has fallen within the competence of the Surveyor General of Poland. Taking into consideration the aim of the INSPIRE Directive - conducting environmental policies - leaving this subject to the Surveyor General of Poland is not a good solution. The data resources in this dataset are supposed to stem from registries kept as part of the EU directive on integrated pollution prevention and control as well as the registration of water intake devices, extraction sites (i.e. mining) and storage sites. In the following years this Directive has been replaced with subsequent directives. The identification of production and industrial facilities is implemented in the context of their influence on the environment, depending on its size, the identification is registered by the national agencies currently supervised by the Ministry of Environment, Provincial Governors, or Local Governments. These entities have the knowledge of terms and norms that should be used to describe industrial 
facilities and productions with an accuracy of a single building. They collect data on them and update that data in context of substantive legal changes, steaming from the improving of the national and European environmental policy. It is hard to expect the geodetic agencies to track the changes in laws pertaining to the granting of, for example, permissions on permissible pollutant emissions, or for them to be familiar with the waste sorting systems and the methods of their disposal. As such, this subject should be assigned to the Ministry of Environment. On the GUGIK website for Registering spatial datasets and data services, this subject is in disarray. For unknown reasons the links to BDOT10k sharing services, BDOO database, and even the topographic raster map files of the Podlasie region were attached to this subject.

\subsubsection{Comments to the dataset for the 4 th subject 'Land use'}

Regarding the land use plans, which are the 4th subject of 3rd Annex, the situation is more complicated, as the Geoportal only serves an integrative role for that data. Administrative units responsible for the creation and updating of the land use plans should make the plans available for browsing and downloading. Currently, many communes in Poland still do not make their land use plans available for browsing with the WMS service or downloading with the WFS service. The list of local governments, together with the way in which the data is shared, is available on the GUGIK website for spatial data.

\subsection{Subjects for which the datasets are available to download}

\subsubsection{Datasets shared by GUS 'Statistical units' (Polish: Jednostki statystyczne) and 'Population distribution - demography'} (Polish: Rozmieszczenie ludności (demografia))

Subject number 1 "Statistical units" (Polish: Jednostki statystyczne) and number 10 "Population distribution - demography" (Polish: Rozmieszczenie ludności (demografia)) of $3^{\text {rd }}$ Annex of the directive are assigned to Statistics Poland (Polish: Główny Urząd Statystyczny; GUS). On the homepage of that agency there is a link to a geostatistics website, on which there is a page about INSPIRE that has a straightforward de- scription of all available datasets and services standardized in the framework of the INSPIRE Directive that this agency has prepared. The first listed service is CSW search standard which allows the search of metadata describing the services and datasets of spatial data published on Geostatistics Portal. The second service that was launched is the WMS browsing service in the framework of which 3 layers have been shared: BREC - current borders of statistical regions and registration districts, GRID - a grid of statistical units (for subject number 1), and for the "Population distribution - demography" subject the sharing of GRID layer with an attribute of a given year has been launched e.g., 2011 - population distribution in a kilometre grid for 2011 and the following years. The downloading of data is possible as both using the ATOM service and as data available directly as *.shp or *.gml files. The updates for $*$.gml data were conducted annually until 2015, and of *.shp data - annually in the period from 2010 till 2019. Diacritic's in *.shp files use Windows- 1250 code page instead of UTF- 8 one.

\subsubsection{Datasets shared by IMGW as part of subjects "Meteorogical geographical features" (Polish: Warunki meteorologiczno-geograficzne), "Atmospheric conditions" (Polish: Warunki atmosferyczne) and "Natural Risk Zones" (Polish: Strefy zagrożenia naturalnego)}

On the websites of Institute of Meteorology and Water Management (Polish: Instytut Meteorologii i Gospodarki Wodnej) there is a lack of any information about INSPIRE data. The Institute shares that data on the ISOK project (IT System for the Country's Protection against Extreme Hazards; Polish: Informatyczny System Osłony Kraju) websites. As part of subject 12, 'Natural risk zones', the website makes the WMS browsing service named 'Natural risk zones (meteorologcal phenomena)' (Polish: Strefy zagrożenia naturalnego (zjawiska meteorologiczne)), and the WFS data downloading service under the same name, available. The data are downloaded without errors and point out areas of heavy rainfalls or strong storms. The remaining services made available there are hard to associate with any particular INSPIRE subject. Nonetheless, to some degree they exhaust the range of data possessed by the Institute. Another WFS downloading service is data from Grid Management System (Measurement and Observation, Hydrological-Meteorogical Net- 
work) (Polish: System Zarządzania Siecią (Sieć pomiarowo-obserwacyjna hydrologiczno-metrologiczna)). That data can be classified as datasets of subject 14 "Meteorogical geographical features" (Polish: Warunki meteorologiczno-geograficzne), as well as of subject number 13 “Atmospheric conditions” (Polish: Warunki atmosferyczne). Additionally, two SOS (Sensor Observation Service) services, "Meteorological observations and measurements" (Polish: Obserwacje i pomiary meteorologiczne) and "Hydrological observations and measurements" (Polish: Obserwacje i pomiary hydrologiczne), from which measurement data can be downloaded, were made available. As for now, this is the only data provider using the SOS service.

\subsubsection{Datasets shared by GDOŚ as part of subjects 'Bio-geographical regions' (Polish: Regiony biogeograficzne) and 'Habitats and biotopes' (Polish: Siedliska i obszary przyrodniczo jednolite)}

Subject number 17, "Bio-geographical regions" is assigned to GDOŚ. In this case, the dataset contains official markings used in the Habitats Directive (92/43/ EWG) and the EMERALD network created in the framework of Berne Convention on the Conservation of European Wildlife and Natural Habitats. Data from this dataset are gathered by the European Environment Agency from the data sent by member states and the agency updates them periodically. Because of this, the link to this subject on the GDOŚ redirect the user to the European Environment Agency website. Data there can be downloaded in the *.shp format and, interestingly, also in the *.sqlite format. Datasets available in both formats are identical. They contain five attributes, including the area number, and its full and short name. The code page for diacritics in the .*shp file is ISO 8859-1, which makes it not compliant with the INSPIRE Directive standards. This is unusual that a dataset can be used by database's programmer or administrator for downloading that dataset with a program over the Internet using the SPARQL client (which is the programming language and the query protocol for the RDF files). Additionally, the GDOŚ website has this layer available as a dataset either for WebGIS browsing or as a WMS layer.

The dataset of subject 18 "Habitats and biotopes" (Polish: Siedliska i obszary przyrodniczo jednolite) is also shared by GDOŚ. It concerns natural phenomena, structural conditions and geographical features. It is one of the few subjects of the 3rd Annex that is available for download via the WFS service. The web address of the service works, is accessible, and all vector layers can be downloaded and saved in one's database or on a drive as a *.gml file. The downloaded layers save the text data in the correct code page, which is UTF-8. The dataset contains six attributes, including, among others, the GID numbers, habitat names, country and INSPIRE codes, and geometry columns. The download test of data from WFS using QGIS version 3.4 proceeded without any problems.

\subsubsection{PIG-PIB shares datasets for subjects "Energy resources" (Polish: Zasoby energetyczne) and "Mineral resources" (Polish: Zasoby mineralne)}

The agency assigned for both subjects is Polish Geological Institute (Polish: Państwowy Instytut Geologiczny) and it makes the MIDAS database accessible over the Internet, which is an integrated database of mineral deposits and contains datasets for both number 20 "Energy resources" and number 21 "Mineral resources" subjects.

The MIDAS system includes all natural resources that in part contain energy resources. They are in no way filtered and it is not possible to download them as a separate resource. To get a dataset concerning only the energy resources, one has to filter the MIDAS dataset, doing so separately for each resource set one by one. It should be emphasized that the datasets have been made available for browsing via the WMS service and WebGIS, and can also be downloaded in *.shp and *.dxf formats. The *.dxf file has no descriptive attribute (contains only the geometry), and the *.shp file contains 14 descriptive attributes, which allows for obtaining quite detailed data. Given the used ISO 8859-1 code page, the datasets do not meet requirement of using the UTF-8 standard.

\section{SUMMARY}

As a result of performed research, the following accessibility of datasets has been determined:

a) 2 subjects have no shared datasets,

b) 1 subject has partially-shared datasets (it depends on local governments),

c) 9 subjects require logging in,

d) 9 subjects has datasets freely available for download without any restrictions, 
In terms of the realization of INSPIRE Directive, we can assume that its implementation in Poland has been achieved to a large degree. 19 out of 21 subjects has the data available. Although, because of the requirements associated with the publishing of open data of public administration, only 9 out of 21 subjects is available to the public. Only 2 out of 9 subjects use the right code pages for their databases.

The basic summary of the research results is, the quantity and type of available open spatial data related to the 3rd Annex of the directive in Poland does not allow for the realization of the directive's aim, which is conducting of environmental policies. There is not enough of open data for them to ease the evaluation of the impact on environment - the results of which are the basis for deciding on further actions related to the environmental protection and land use planning. It ought to be emphasized that much spatial data has been created and is being shared after getting relevant permissions, and companies and agencies realizing tasks related to the environmental policy will receive necessary access to the data. Instead, the persisting problem is the commonness of their use and the lack of public participation in wider shaping of the environmental policy that is related to it.

Worth noting here is the fact of very uneven data spread among the subjects of the 3rd Annex. For example, the Chief Inspectorate of Environmental Protection shares one dataset of "Bio-geographical regions" subject, which consists of a dozen or so of areas. The last update of this layer took place in 2016. The same agency shares as many as 152 datasets, related to the location of sampling points, in the "Environmental monitoring facilities" subject in the following categories: natural environment (background measurements), information on Earth Science, monitoring of air pollution (several networks), monitoring of surface water and groundwater contamination, monitoring of sewage dumping, society, environmental protection infrastructure, climatology/meteorology/atmosphere, fauna and flora. These measurements are conducted at different frequencies (more and more permanent sampling points emerge) and they are not always conducted in the same points, which results in the necessity of annual updating of the measurement net layers. This results in the high burden from data updates, and a large number of them being simultaneously available to the user.

In addition to that, worthy of mention are the positive actions of GUGIK in regard to the national geopor- tal, as a new map server called "Geoportal INSPIRE" has been created for it. The server shares not only links to subjects of the 1st and the 2nd Annex, but also makes 7 out of 21 subjects of the 3 rd Annex of the INSPIRE Directive available for browsing. This really sorts the data and makes the browsing of it easier. Meanwhile, the GUGIK website for Registering Spatial Datasets and Data Services, in its current shape, tries to follow the rule of BDOT10k dataset being inserted into places where there is actual lack of data.

The necessity of discussing in the future the topic of analysing the quality of the shared spatial data, also needs to be highlighted. The participation in that process of the local communities that can verify some of the datasets on-site, would be required. It would take place with the benefit for the dataset, and also authenticate/lend credibility to the data update process. In the future, such actions and working together seems to be indispensable.

\section{CONCLUSIONS}

The main conclusion from this research is the necessity of introducing organisational changes in the context of the responsibility of government agencies for some of the subjects of the $3^{\text {rd }}$ Annex. The national and local geodetic agencies that have county and province facilities should be included into the "Agricultural and aquaculture facilities' subject. The Falenty Institute assigned to this subject, in current legal and organisational conditions, is not capable of acquiring data on the national scale. Meanwhile, the expanded geodetic agencies can use their resources to assist in the creation of datasets regarding the irrigation systems used in Polish agriculture. Taking the legal regulations and the technical abilities and competence of the geodesy workers into consideration, especially their knowledge of the area, they can significantly contribute to the data delivery and the data being up-to-date for this subject.

Another subject that should be assigned to a different leading agency is the 'Production and industrial facilities' dataset. This dataset should end up in competence of the Minister of the Environment, so that the entities providing any kind of business licences, permissions and other authorisations related to the use of the environment, could assign selected data from the documentation in their possession that is created for the purpose of acquiring them. The geometry off all buildings and civil structures, including industrial ones, is managed 
in the 'Buildings' dataset, which is already assigned to GUGIK. And in this specific dataset, the geometry of buildings should be managed (edited), whereas the datasets of the "Production and industrial facilities" subject should contain data for groups of buildings comprising an entity carrying out industrial and manufacturing activities related to the emission and the discharge of pollutants, and the storage and disposal of waste.

Organising of datasets and the management of their maintenance does not necessarily have to be based on a ministerial distribution of competencies. The creation of objects, as well as their maintenance, should be organised through the creation of a data preparation system that would let each agency use the resources of other bodies to expand its own dataset. Their publication should also be integrated into a single place on the Internet. Currently, gathering the scattered links for all 21 datasets is very difficult. The datasets 12 , "Natural risk zones", of the 3rd Annex are most noticeably affected by the split between agencies. There are many physical phenomena in the three spheres where the nature generates risk zones - e.g., landslides, droughts and tornadoes. Because of this, the datasets of this subject should be created by several institutions.

The scientific conclusion of the performed analysis is the identification of the problem of assigning classification priorities for spatial data of INSPIRE subjects. The approach for the subject assignment for specific resorts up until now could be described as "the dominance of geometry", where a given subject is associated first with the geometry of objects and then their type. Meanwhile, the subjects of the INSPIRE Directive are, first and foremost, the identification of data domain in the framework of which the datasets are to be created. More important and more relevant are the objects in the form of named and identified dataset entities (e.g., with an unique ID or name), and not the object's geometry, which is only its property and should be generated once and then managed within a single subject, and from that subject further used in other subjects.

The technical conclusion is the recommendation of sharing the data in the form of spatial data files in * sqlite format instead of *.shp, due to Spatialite by default using the UTF-8 code page, in compliance with the INSPIRE standards.

Several of the analysed data sets contain very few descriptive attributes. The user obtains the geometry of the objects, which does not contain a large number of attributes. Enriching the description of attributes is necessary to increase the functionality of cartographic data (Krawczyk, 2018)

The need for taking measures in the context of analysing the quality of shared spatial data, should also be stressed. The participation of local communities, that can verify some of the datasets on-site, in this process would be required. It would be beneficial for the dataset, as well as would authenticate the process of updating the data. In the future, taking such actions and working together seems indispensable, especially in the framework of the directive on open data of public administration.

\section{ACKNOWLEDGMENT}

The article was prepared under the research subvention of AGH University of Science and Technology No. 16.16.150.545 in 2020.

\section{REFERENCES}

Bac-Bronowicz J., Górniak-Zimroz J., and Pactwa K. (2016): Wykorzystanie państwowych rejestrów geoprzestrzennych w środowisku GIS do identyfikacji środowiskowych i społecznych konfliktów spowodowanych odkrywkową eksploatacją złóż surowców zwięzłych (Using of geospatial national registers in GIS environment for identification of social and environmental conflicts caused by opencast exploitation of solid raw materials). Annals of Geomatics, 14(4(74)):413-426.

Dąbkowski S. L., Gugała M., and Kula A. (2014): Wdrażanie dyrektywy INSPIRE w Polsce w aspekcie zakresu ewidencji i stanu obiektów melioracji wodnych 2013. Woda-Środowisko-Obszary Wiejskie, 14(2):35-47.

Gaździcki J. (2017): Wybrane problemy w zakresie informacji geoprzestrzennej w Polsce (Selected geospatial information issues in Poland). Annals of Geomatics, 15(3(28)):283-292.

Garguła A. and Krawczyk A. (2018): Harmonization of Polish Natura2000 data sets with the protected sites data schema of inspire Directive in the environment of Humboldt Alignment Editor (HALE). Geoinformatica Polonica, 17:7-15.

Geiger C. P. and von Lucke J. (2012): Open government and (linked) (open) (government) (data). JeDEM - eJournal of eDemocracy and Open Government, 4(2):265-278.

Kaczmarek I., Iwaniak A., and Łukowicz J. (2014): New spatial planning data access methods through the implementation of the INSPIRE directive. Real Estate Management and Valuation, 22(1):9-21.

Kozakiewicz R. (2015): Possible use of spatial information listed in INSPIRE Directive in Environmental Impact Assessment. Geomatics and Environmental Engineering, 9(2):41-50.

Krawczyk A. (2018): A concept for the modernization of underground mining master maps based on the enrichment 
of data definitions and spatial database technology. E3S Web of Conferences Vol 26 EDP Sciences.

Krawczyk A. (2019): Geomatyka i geoinformacja górnicza, ich praktyczne zastosowania i bariery rozwoju. Rozprawy Monografie. Wydawnictwa AGH, Kraków.

Michalak J. (2004): Multilingual European subset of unicode in geospatial data encoding. Annals of Geomatics, 2(1):53-66.

Parliament, E. and Council, E. (2007): Directive 2007/2/EC 14 March 2007 Establishing an Infrastructure for Spatial Information in the European Community (INSPIRE). OJ L 108 24.4.2007.

Parliament, E. and Council, E. (2014): Directive 2011/92/EU 16 April 2014 on the assessment of the effects of certain public and private projects on the environment. L 124/1 25.4.2014.

Parliament, E. and Council, E. (2019): Directive 2019/1024/EU 20 June 2019 on open data and the re-use of public sector information. L 172/56 26.6.2019.

Pluta M. (2016): Spatial planning in Poland in the context of INSPIRE rules and amendment to the spatial planning and development act. Geomatics, Landmanagement and Landscape, 4:159-168.

Pluto-Kossakowska J., Marczak S., and Radło-Kulisiewicz M. (2016): Ocena potrzeb i możliwości wykorzystania bazy danych przestrzennych obiektów rolniczych i akwakultury (ORA) w modelu podstawowym. Annals of Geomatics, 14(5(75)):617-626.

Quarati A. and Martino M. D. (2019): Open government data usage: A brief overview. In Proceedings of the 23rd International Database Applications \& Engineering Symposium, IDEAS '19, New York, NY, USA. Association for Computing Machinery.

Sejm, R. P. (2008): Ustawa z dnia 3 października 2008 r. o udostępnianiu informacji o środowisku i jego ochronie, udziale społeczeństwa w ochronie środowiska oraz o ocenach oddziaływania na środowisko. Dz.U. 2013, poz. 1235 , consolidated text, Dz.U. 2008 nr 199 poz. 1227.

Sejm, R. P. (2010): Ustawa z dnia 4 marca 2010 r. o Infrastrukturze Informacji Przestrzennej. Dziennik Ustaw, $2010 \mathrm{r}$. Nr 76 poz. 489. tekst jednolity: Dz. U. 2020 r. poz. 177. 